\title{
KONVERGENS MODELLEZÉS ÉS REVERSE ENGINEERING
}

\author{
Tóth Sándor Gergő \\ PhD hallgató, Miskolci Egyetem, Szerszámgépek Intézeti Tanszéke \\ 3515 Miskolc, Miskolc-Egyetemváros \\ Hegedüs György \\ egyetemi docens, Miskolci Egyetem, Szerszámgépek Intézeti Tanszéke \\ 3515 Miskolc, Miskolc-Egyetemváros, e-mail: hegedus.gyorgy@uni-miskolc.hu
}

\begin{abstract}
Absztrakt
A reverse engineering módszerek gyakorlati alkalmazásával az utóbbi időben egyre gyakrabban merülnek fel a visszamodellezett objektumokon végzett tervezési feladatok. Korábban a pontfelhö alapú geometriai elemeken végezhetö müveletek korlátosak voltak, azonban az elmúlt években bevezetett konvergens modellezési technológia ezeket a korlátokat feloldotta. Jelen cikkben a konvergens modellezési technológia néhány gyakorlati példáját ismertetjük.
\end{abstract}

Kulcsszavak: konvergens modellezés, reverse engineering

\begin{abstract}
With the practical application of reverse engineering methods, design tasks on re-modeled objects have become more frequent recently. Previously, operations on point cloud-based geometric elements were limited, but convergent modeling technology introduced in recent years has overcome these limitations. This article describes some practical examples of convergent modeling technology.
\end{abstract}

Keywords: convergent modelling, reverse engineering

\section{Bevezetés}

A számítógéppel segített tervezés története egészen 1957-ig nyúlik vissza, amikor Patrick J. Hanratty - akit a CAD/CAM szülőatyjának is neveznek - létrehozta PRONTO néven az első CAM szoftvert. A következő fontos állomás 1960-ban volt, amikor Ivan Sutherland megalkotta a Sketchpad nevü alkalmazását, ahol a felhasználó egy fényceruza segítségével rajzolta meg a geometriai objektumokat, amit egy képernyőn jelenített meg. Ezt követően az elektronikai és számítástechnikai eszközök fejlődésének köszönhetően újabb és újabb alkalmazások jelentek meg. A hardver és szoftver fejlesztését elsősorban a repülőgép- és jármüiparban meghatározó vállalatok jelentették. A személyi számítógépek megjelenésével és azok elterjedésével a független CAD/CAM szoftverfejlesztők és hardver gyártók is előléptek. A számítógépi geometriai adatok megjelenítése, feldolgozása - a hardverrel párhuzamosan - folyamatosan fejlödött. A kezdeti időszakban alapvetően a kétdimenziós analitikusan meghatározható - geometriai elemek megjelenítésén volt a hangsúly. A felhasználói igények következtében azonban szükség volt a szabadformájú térbeli görbék kezelésére is, melyeknek matematikai megvalósítása Pierre Bezier és Paul de Casteljau francia származású tervezőmérnökökhöz köthető. Pierre Bezier a Renault autógyártónál a gépjárművek karosszéria elemeihez használt parametrikus szabadformájú görbéket és felületeket a geometria megadásához. A róla elnevezett Bezier görbék és felületek a Bernstein-polinomokat - melyek már 1912 óta ismertek - 
használják az adott geometriai egyenletben, azonban a meghatározásukhoz szükséges nagyigényü számítási kapacitás miatt nem alkalmazták a számítógépi grafikában. Az áttörést a Paul de Casteljau által kidolgozott és róla elnevezett de Casteljau algoritmus jelentette. Az eljárás többszörös lineáris interpolációk sorozatával határozza meg a görbe pontjait, előnye, hogy a megoldás elóállítása numerikusan stabilabb eredményeket ad [1]-[3].

$\mathrm{Az}$ 1970-es években a számítógéppel segített rajzolás súlypontja a 2D-s müszaki rajzok reprodukciójáról eltolódott a 3D-s komplex drótváz modellek alkalmazása felé, köszönhetően a korábban lefektetett matematikai eljárások számítógéppel történő meghatározásához és az eredmények megjelenítéséhez. Ebben az időszakban már megkezdődtek a szilárdtest (térfogat) modellezés fejlesztései is. Az első kereskedelmi forgalomban megjelent a SynthaVision nevü szoftver volt, melyet a MAGI (Mathematical Applications Group, Inc) fejlesztett. A szoftvert alapvetően nukleáris sugárzás nyomon követésére alkalmazták, melynek meghatározásához szilárd alakprimitíveket, boolean müveleteket és ray-tracing technikát alkalmaztak. 1978 áprilisában megjelent a Unigraphics Rl (UGS Corp./McDonnell Dougles), 1981-ben kezdték fejleszteni a GEOMOD (SDRC) első verzióját. Az 1980-as években a szabadformájú felületek (Bezier, B-szplájn, NURBS, Coons) és az azokkal végzett müveletek váltak elterjedté a számítógépi grafikában, valamint a CAD szoftverekben. A következő mérföldkő a Pro/ENGINEER Rl verziójának megjelenése volt 1987-ben. A szoftver a mai integrált tervezőrendszerek elődjének tekinthető, melyben bevezették az asszociatív, alaksajátosság alapú, parametrikus szilárdtest modellezést. A parametrikus rendszerek egyik fő jellemzője a modellalkotás tekintetében a modelltörténet. A különböző szoftverek közötti termék adatcserét a szabványosított, rendszersemleges fájlformátumok biztosítják, azonban a konverziós adatvesztés mellett másik hátrányuk a modelltörténet hiánya. Az ilyen modellek módosítása a paraméterek és modelltörténet ismerete nélkül időigényes, a probléma megoldására a szoftverfejlesztők az explicit (direkt) modellezés és a szinkronmodellezési technológiákat vezették be a 2000-es évek végétől kezdődően, ami lehetővé tette a geometria módosítását a topológia ismeretében. Megemlítendő, hogy 1993-ban már megjelent kereskedelmi forgalomban az első explicit modellezési technológiát alkalmazó CoCreate szoftver, azonban a Pro/ENGINEER programban bevezetett alaksajátosság és modelltörténet alapú modellezési technológia térhódítása a CoCreate megoldásait háttérbe szorította.

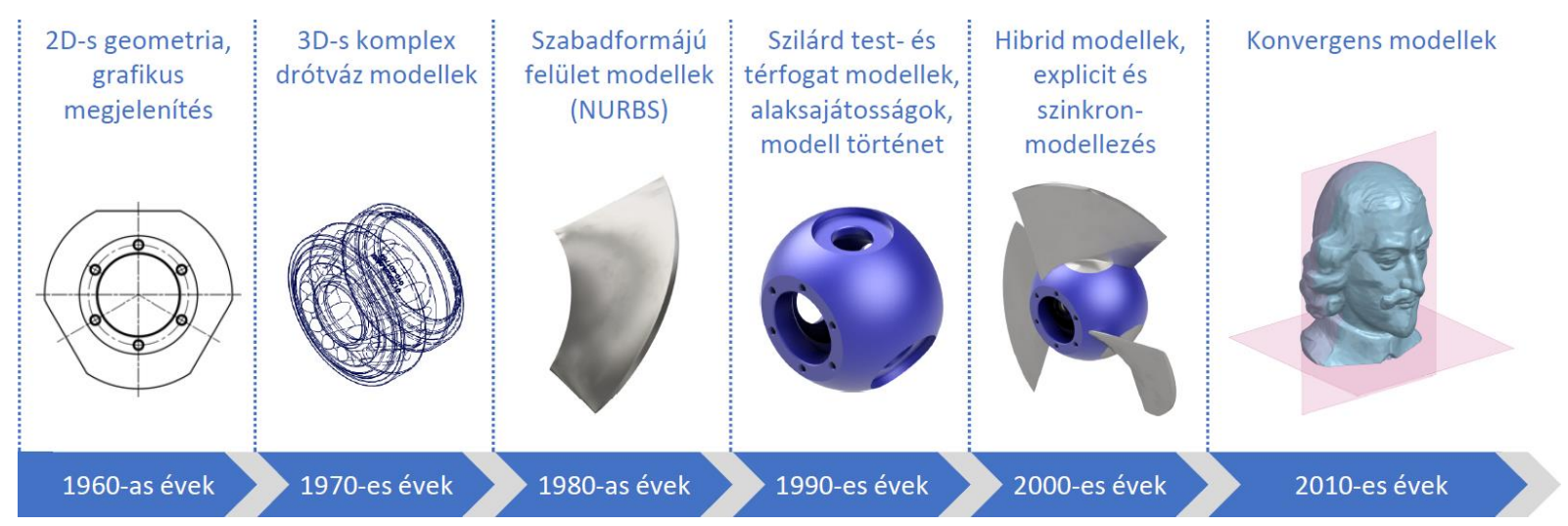

\section{1. ábra. A CAD modellek típusai}

A gyors-prototípusgyártás (Rapid ProtoTyping - RPT) és a Reverse Engineering eljárások következtében az elmúlt években szükségessé vált a hálómodellek (poligon modellek) adott rendszeren belül megvalósítható módosítása is. Az ilyen modellek kezelésére alkalmas a konvergens modellezési technológia (1. ábra). 


\section{Alkalmazott modellek a gépészeti tervezésben}

Az előző fejezetben ismertetett rövid történeti áttekintés mérföldköveinek megfelelően látható, hogy a gépészeti tervezéskor - a geometriai tulajdonságok tekintetében - többféle modellel kell müveleteket végrehajtanunk. Az alábbiakban ezeket foglaljuk össze röviden.

1. Drótváz vagy huzalváz modell: a drótváz modellek csak pontokkal és élekkel valósítják meg a 2D-s, 3D-s objektumok ábrázolását Kétdimenziós drótváz modelleket 2D-s müszaki rajzok létrehozásához, egyszerü komponensekhez vagy NC pálya generálásához alkalmaznak. A drótváz modellek képezhetik a felület, vagy térfogat modellek alapját is. A drótváz elemei meghatározhatják a komponensek síkbeli vagy térbeli helyzetét, azonban nem egyértelmüen ábrázolhatják a térbeli objektumokat, mivel a felületek árnyékolt megjelenítésére, az anyagjellemzők definiálására nincs lehetőség. A gépészeti modellezésben ezeket a típusú modelleket jelenleg ritkán használjuk.

2. Felületmodell: a felületmodellek térbeli objektumok leírására alkalmasak. A felületek megadhatók egyszerü egyenletekkel (pl. sík, henger, kúp), valamint szabadformájú felületek (Bezier, B-spline, NURBS) formájában kontrolpontokkal vezérelve. A felületmodellekkel elsősorban jármüipar (pl. karosszéria elemek), repülőgépipar (pl. szárnyprofil), energetika (pl. turbina, szivattyú járólapát) és az ezekhez kapcsolódó szerszámtervezés területén találkozhatunk. A felületmodellek takartvonalas és árnyékolt megjelenítése is lehetséges, azonban az anyagjellemzők megadására itt sincs lehetőség.

3. Háló vagy poligon (sokszög) modell: a poligon modellek az objektumokat háromszögek vagy négyszögek halmazával írja le. A gépészeti tervezésben ezek a modellek leggyakrabban a 3D szkennelés eredményeként jönnek létre, valamint az .stl fájlformátumra történő konverzióként. A geometria leírása a sokszögek csúcspontjaival és a sokszögek által bezárt felületfolt normálisával történik. Az objektumok takartvonalas és árnyékolt megjelenítésére van lehetőség, de anyagjellemzők megadása ennél a típusnál sem lehetséges.

4. Szilárdtest modell: a szilárd testek modellezésére többféle eljárás is létezik a gyakorlatban. Ezek közül a CAD modellezésben a határfelület reprezentáció (Boundary-representation - B-rep), vagy palástmodell, illetve az elemi testekkel (alakprimitívekkel) történő modellezés a legelterjedtebb.

- A palástmodell a modellezett objektum határolófelületeit felhasználva írja le a geometriát. A drótváz modellnél megismert csomópontok és élek mellett az élekkel határolt zárt felületelemet is definiálja a topológiában (2. ábra).

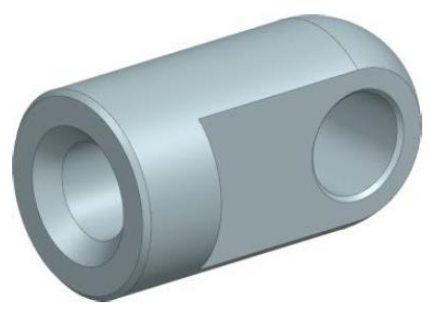

Szilárdtest modell

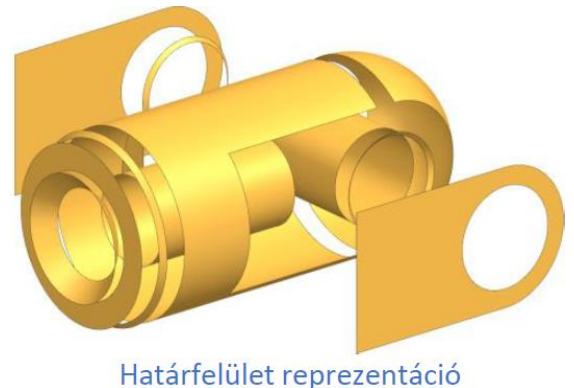

Határfelület reprezentáció

2. ábra. Szilárdtest modell és határfelület (B-rep) reprezentácója

A gyakorlatban kétféle palástmodell fordul elő, az egyik a poliéderes palástmodell, ez a modellezett objektumot sík felületelemekkel írja le vagy közelíti. Analitikusan megadott 
görbült felületek modellezésére is van lehetőség, de ezek explicit formájúak lehetnek csak, így alkalmazhatóságuk korlátozott. A másik - elterjedtebb - palástmodell a szabadformájú felületek használatát is támogatja, így az objektumot az ábrázolási pontosságnak megfelelően definiálhatjuk. A palástmodellek alkalmasak térfogat és - az anyagjellemzők ismeretében tömegszámításra, ütközés vizsgálatok elvégzésére, végeselem hálókészítésre, illetve gyártástechnológiai tervezések elvégzésére [4].

- Térfogatmodell: konstruktív szilárd geometria (Constructive Solid Geometry - CSG), amely a teljes tömör ábrázolását adja az objektumnak. A modellezés alakprimitívekből (hasáb, henger, kúp, gömb, tórusz) hozza létre a végleges geometriát, különböző halmazalgebrai (boolean) müveletek (kivonás, összeadás, metszet) alkalmazásával (3. ábra).

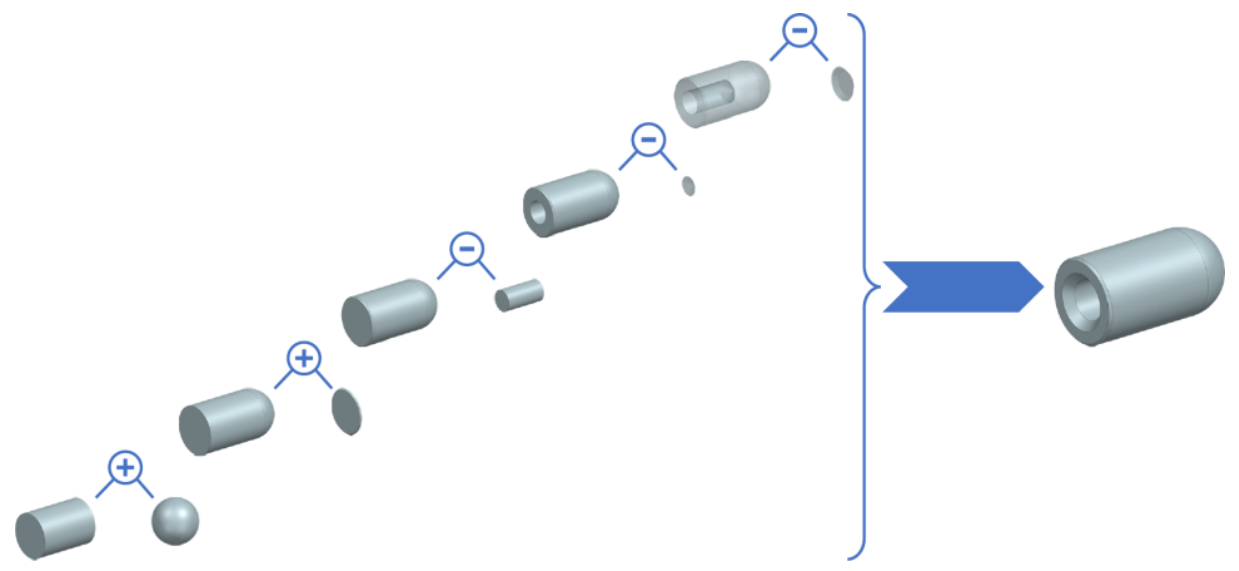

3. ábra. CSG modellezés alakprimitivekkel és boolean müveletekkel

Az említett szilárdtest modellező technikákon kívül léteznek még további eljárások is, mint például a féltér-módszer, hasáblebontó módszer, elemi sejtekkel való modellezés, söprés, azonban a napjainkban elterjedt modellező kernelek CAD moduljai a fent említett két eljárást alkalmazzák.

5. Hibrid-modell: a hibrid modellek a fenti geometriai modelleket ötvözik, ami legtöbbször felület- és szilárdtest modell (pl. szerszámtervezésnél), valamint poligon- és szilárdtest modell (pl. szkennelt objektumok modellezésénél).

\section{Esetpéldák konvergens modellezésre}

A Szerszámgépek Intézeti Tanszékén több éves tapasztalat és ismeret halmozódott fel a reverse engineering területén [5]. A rendelkezésre álló hardver (Breuckmann Smartscan 3D-HE optikai szkenner) és szoftver (Siemens PLM NX) segítségével lehetőség nyílik a szkennelt objektumok visszamodellezésére. A szoftverben 2017-ben bevezetett konvergens modellezés a parametrikus és a poligon modellezésre épülő technológiák előnyeit ötvözi. A hagyományos hálómodellként importált fájlokkal való müveletek korlátozottak, azonban a gyakorlatban egyre gyakrabban fordulnak elő olyan feladatok, ahol a szkennelt objektum módosítása, áttervezése, CNC megmunkálása, vagy 2D-s müszaki rajzdokumentációja szükséges. A szkennelt objektumról rendelkezésre álló állományt konvergens modellként importálva lehetőségünk nyílik hibrid modell létrehozására, ahol használhatjuk az alaksajátosságalapú modellezési müveleteket. Az alábbi két eset erre a modellezési technológiára mutat szemléltető példákat. 
1. Emlékplakett készítése 3D CNC technológiával

Ennél az esetnél a feladat egy rendelkezésre álló szobor (fej-, vagy mellszobor) alapján egy emlékplakett elkészítése volt (4. ábra). Az ilyen müvészeti alkotásoknál a szkennelési pontosság másodlagos, azonban a problémát a visszamodellezés során a meglévő objektumon található alámetszések jelenthetik, ami az utómunkálatok müveleti idejét növelhetik.
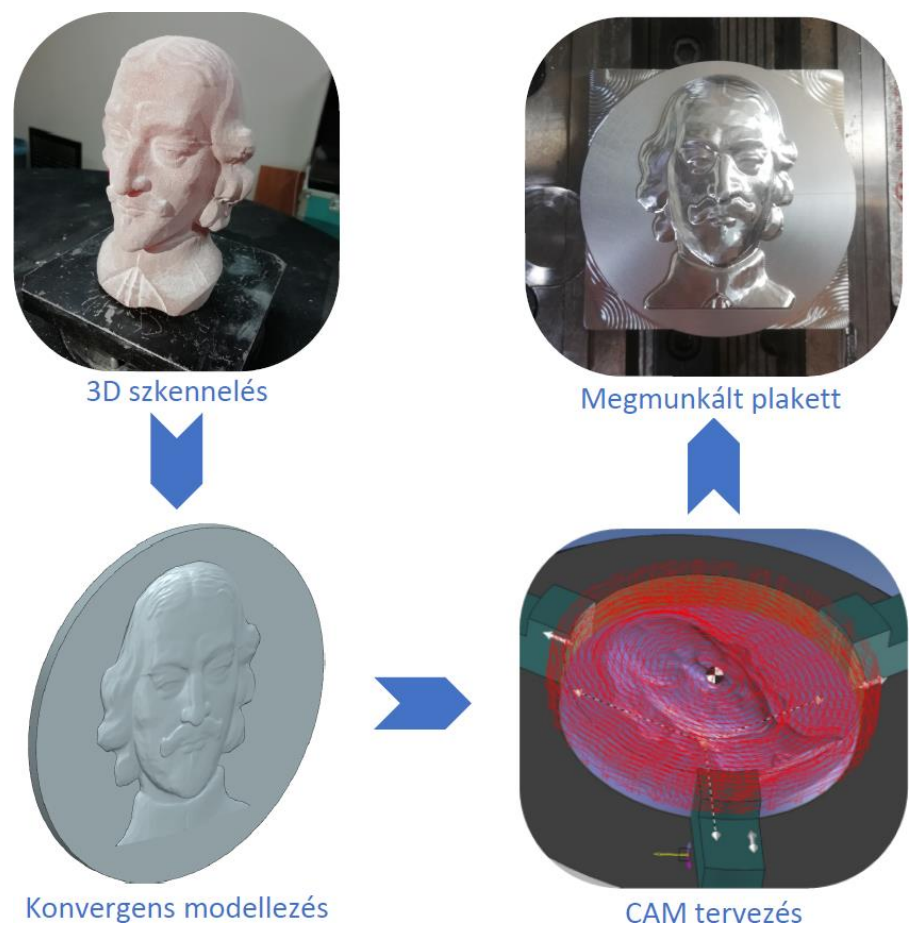

4. ábra. Emlékplakett gyártása szkennelt objektumból

2. Szivattyútengely $2 \mathrm{D}$-s müszaki rajzának elöállítása

A következő példa egy öthengeres dugattyús szivattyú fő́tengelyének 2D-s müszaki rajdokumentációjának előállítását szemlélteti. A tengelyt egy kovácsolt előgyártmányból, az illesztett felületek utólagos megmunkálásával állítják elő. A megmunkált felületek geometriai szempontból - egyszerü, hengeres felületek, melynek mérése hagyományos eszközökkel mérhetö. A tengely befoglaló méretei $(l=1015,5 \mathrm{~mm})$ miatt a munkadarab mérése a rendelkezésre álló mérőgépen nem valósítható meg és tömege $(m=60 \mathrm{~kg})$ miatt a mozgatása is körülményes a mérési müveletekhez. További mérési nehézséget okoznak a kovácsolt elögyártmányon található szabadformájú felületek, lekerekítési ívek és átmenetek, melyek mérése időigényes. Az ehhez hasonló eseteknél előnyösen alkalmazhatók a 3D szkennelési eljárások a munkadarab méreteinek felvételéhez. A szivattyú müszaki rajzdokumentációja hiányzik, emiatt javításkor, felújításkor vagy cserealkatrész gyártásakor szükséges egy 2D-s müszaki rajzdokumentáció, ami alapján az alkatrész gyártáshoz (pl. forgácsolás) szükséges méretei, türései, illesztései leolvashatók. Az 5. ábra a fötengely müszaki rajzdokumentációjának elóállításához szükséges főbb lépéseket szemlélteti. A visszamodellezés során lehetőség nyílt a felújított tengely méreteinek ellenőrzésére is (a meghibásodás oka a tengely meghajlása volt, amit egyengetéssel és az illesztett felületek felszabályozásával javítottak). 

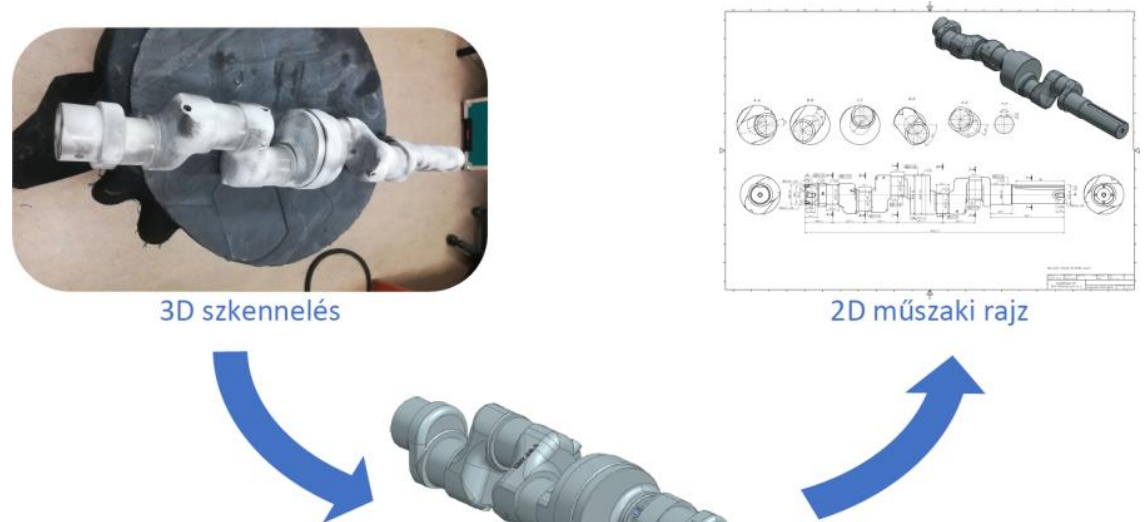

2D müszaki rajz

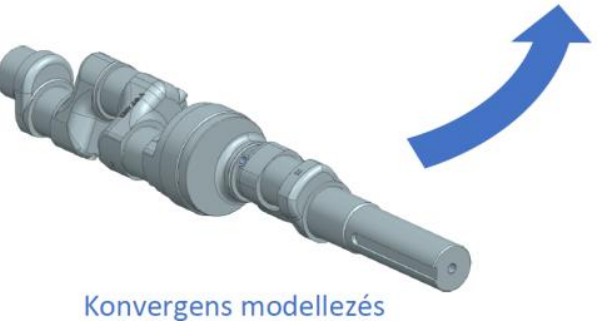

5. ábra. Öthengeres dugattyús szivattyú fötengelyének konvergens visszamodellezése

A mérések alapján megállapítható volt, hogy a tengely tömegközéppontja és inercia tengelyei eltérnek az ideális állapottól, így ezen tulajdonságokat utólag szerelt póttömegekkel beállítják.

\section{4. Összefoglalás}

Jelen cikkben röviden áttekintésre kerültek a számítógépes geometriai modellezésben elterjedt különböző geometriai objektumok. A reverse engineering alkalmazások térnyerésének következtében bevezetett legújabb konvergens modellezési technológia lehetőségei gyakorlati alkalmazásokon keresztül kerültek bemutatásra.

\section{Köszönetnyilvánítás}

A cikkben ismertetett kutató munka az EFOP-3.6.1-16-2016-00011 jelü „Fiatalodó és Megújuló Egyetem - Innovatív Tudásváros - a Miskolci Egyetem intelligens szakosodást szolgáló intézményi fejlesztése" projekt részeként - a Széchenyi 2020 keretében - az Európai Unió támogatásával, az Európai Szociális Alap társfinanszírozásával valósul meg.

\section{Irodalom}

[1] Farin, G., Hoschek, J., Myung-Soo, K.: Handbook of computer aided geometric design, Amsterdam, Elsevier, 2002, ISBN 0-444-51104-0

[2] Hirz, M., Dietrich, W., Gfrerrer, A., Lang, J.: Integrated computer-aided design in automotive development. Heidelberg, Springer, 2013, ISBN 978-3-642-11939-2

[3] Stroud, I., Nagy, H.: Solid Modelling and CAD Systems, London Springer, 2011, ISBN 978-085729-258-2 https://doi.org/10.1007/978-0-85729-259-9

[4] Stroud, I.: Boundary Representation Modelling Techniques, London, Springer, 2006, ISBN 978-1-84628-312-3

[5] Csáki, T., Lajtos, J., Makó, I., Szilágyi, A.: Reverse engineering alkalmazási lehetöségei, GÉP LXIII, 2012(3), ISSN 0016-8572 